\begin{tabular}{|l|l|l|l|l|}
\hline \multirow{2}{*}{ aptara } & CUAN & cuan_1146 & Dispatch: February 22, 2012 & CE: N/A \\
\cline { 2 - 5 } & Journal & MSP No. & No. of pages: 25 & PE: Sarah \\
\hline
\end{tabular}

\title{
THE SEMIOTICS OF SECURITY: Infectious Disease Research and the Biopolitics of Informational Bodies in the United States
}

\author{
CARLO CADUFF \\ University of Zurich
}

"This excess of biopower appears when it becomes technologically and politically possible for man not only to manage life but to make it proliferate, to create living matter, to build the monster, and, ultimately, to build viruses that cannot be controlled and that are universally destructive. This formidable extension of biopower ... will put it beyond all human sovereignty."

-Michel Foucault, "Society Must be Defended"

I first learned about the quandary in which she found herself at the international conference on Options for the Control of Influenza meeting in Toronto in June 2007. Mobilized by the presumable threat of a global pandemic, a record attendance of 1,600 delegates from more than 66 countries gathered to discuss measures for influenza detection, containment, and prevention. I had already encountered Dr. Taronna Maines, a microbiologist and influenza researcher, a few months earlier when I visited her lab at the Centers for Disease Control and Prevention (CDC) in Atlanta, Georgia. My visit to Atlanta had been occasioned by a research article that Dr. Maines and her colleagues at the influenza branch of the disease control centers had recently published in a prestigious journal, the Proceedings of the National Academy of Sciences. In the article, the scientists reported preliminary results of a series of experiments conducted with a set of genetically engineered flu viruses (Maines et al. 2006). According to Dr. Maines, the main purpose of the research was to evaluate the pandemic potential of the H5N1 avian influenza virus that was rapidly 
sweeping across Asia, Europe, and Africa at the time. What biomedical experts and public health professionals feared most was that the notoriously unpredictable virus might exchange genes with an ordinary human virus, obtain the transmissibility of regular seasonal flu, and become a highly contagious pathogenic agent causing a global pandemic.

Within this historically distinctive context marked by an uncertain microbial entity, a growing biopolitical pressure, and an acute sense that the future was at stake, Dr. Maines and her colleagues designed an experimental system to explore under controlled conditions what might actually happen if the avian virus would suddenly mix its genes with a highly transmissible human virus. Addressing an important question currently investigated in experimental research, Dr. Maines and her colleagues wondered why some viruses pass more easily among humans. The project garnered considerable public attention and was covered in newspaper articles (Chong 2006; Grady 2006).

Deploying a sophisticated technology of reverse genetics originally developed by a group of microbiologists headed by Dr. Peter Palese at Mount Sinai School of Medicine in New York, where I conducted a significant part of my fieldwork on pandemic influenza, Dr. Maines carefully constructed a number of hybrid strains in the laboratory. These genetically engineered strains contained genes from both avian and human influenza viruses. Not surprisingly, most of the genetic combinations produced microbial creatures that were not viable at all, and the main technical challenge was to find genes "that are happy together," as Dr. Maines phrased it in a conversation with me. The pandemic potential of those genetically engineered viruses that replicated efficiently and grew well under laboratory conditions was then investigated in an animal model.

In early 2006, Dr. Maines received a fresh stock of male ferrets, six to 12 months of age, raised at a commercial farm in the hills of northern Pennsylvania and delivered by truck to the disease control centers. In the laboratory, 12 animals were infected with a low dilution of the genetically engineered avian-human flu strains. Ferrets are considered the most reliable animal model for the experimental investigation of the transmission of influenza viruses, and Dr. Maines observed them closely over the next few days, although no transmission took place. None of the hybrid strains, whose genes were "happy together," appeared to be able to spread easily from animal to animal despite genetic combination with influenza viruses known for efficient transmission. In its current state, Dr. Maines and Dr. Terrence Tumpey explained to me, the $\mathrm{H} 5 \mathrm{~N} 1$ avian influenza virus seemed to require further 
With these experimental results on the table, Dr. Maines found herself entangled in a difficult quandary, as she told me over lunch at the Options for the Control of Influenza meeting. As long as it would remain impossible for her to construct hybrid strains that pass in the laboratory from ferret to ferret, it would not be feasible for her to publish further research about the transmission of the H5N1 avian flu virus. Only positive experimental results would make possible another publication in a journal. Publishing positive results that demonstrate the capacity to adapt the avian virus in the laboratory by technical means and transform it into a contagious agent, however, would be equally difficult, if not impossible. Even though it might provide important scientific information regarding the pandemic potential of the virus and possibly reveal some of the biological factors responsible for the transmission of the flu, such an article, Dr. Maines explained to me, would inevitably provoke serious security concerns among government officials, and perhaps rightly so. At stake for Dr. Maines, however, was not just the fate of a particular research project, but the very possibility of participating in the moral economy of scientific exchange (Daston 1995; Kohler 1994). No matter what her experimental endeavors would eventually produce, be it positive or negative results, Dr. Maines increasingly felt that her research was inextricably trapped in an expanding script of security. Growing concerns with security, as I gradually came to realize in the course of my fieldwork, loomed large on the horizon of infectious disease researchers in the United States. Paradoxically, these concerns were both enabling and disabling, as Dr. Maines's project vividly demonstrated, opening up and closing down promising avenues in the competitive world of cutting-edge science.

In this article I investigate a set of intensive security debates about infectious disease research. As Ronald Atlas and Judith Reppy remarked in a sweeping 2005 publication, "in the current paradigm, all infectious disease research is potentially relevant to bioterrorism and may be implicated in controversies over the motivation and possible uses of the research" (Atlas and Reppy 2005:52). According to Gerald L. Epstein, infectious disease research has become "contentious research" because it may generate information "that could have immediate weapons implications" (Epstein 2002:398). Concerns with security are not new, to be sure. In fact, infectious disease research has always been politically charged in many respects, but it is now even more so, and in a very particular way. My aim here is to explore how concerns over security have sparked a contentious debate about biological research and its mandates, responsibilities, and accountabilities over the past few years. What might an anthropological analysis of science and security be able to tell us about the ways in which "life" is made a new political concern today? 
cuan_1146 can2008.cls February 22, $2012 \quad 14: 0$

Drawing on Michel Foucault's lectures at the Collège de France, I first examine the apparatus of security and its constitutive problematic of circulation. I specifically suggest that, within the context of infectious disease research, security experts have not been primarily concerned with the circulation of biological matter, as Erin Koch, Andrew Lakoff, Celia Lowe, Kathleen Vogel and others have argued in their examinations of today's biosecurity formations (Koch 2008; Lakoff 2008; Lakoff and Collier 2008; Lowe 2010; Vogel 2008). ${ }^{1}$ These experts, I suggest, have also begun to focus on the exchange of scientific information. It is true, of course, that experts have continued to be concerned with the dissemination of biological matter and technological equipment - potentially dangerous scientific information is worthless, after all, without simultaneous access to the complex and sophisticated material infrastructure necessary to manipulate pathogenic agents in the laboratory. But the concern with scientific information that has been expressed over the past few years in relation to contemporary infectious disease research has nonetheless affected the biopolitical economy of security in distinctive ways.

The focus on scientific information as a "security threat" is new in the context of infectious disease research, to be sure; it is not new, of course, in the context of the nuclear program, where the focus of state security experts has always been on both dangerous matter and sensitive information (Galison 2004; Gusterson 1996; Masco 2006). What is specific about the biological sciences, however, is that - in contrast to the physical sciences - it is matter itself that is increasingly understood in informational terms (Fox Keller 2000; Kay 2000; Rheinberger 2000; Sunder Rajan 2006; Thacker 2006). Biological matter, in other words, is generally considered informed matter today. My aim, consequently, is to attend to the historically distinctive effects of this informational redefinition of biological materiality for the biopolitical economy of security.

\section{INFORMATION COMES TO MATTER}

"Deadliest Flu Bug Given New Life in U.S. Laboratory," a San Francisco Chronicle article announced in early October 2005. The article reported that U.S. scientists had re-created in the laboratory "a living copy of the deadly flu bug responsible for the catastrophic 1918 Spanish influenza epidemic" (Russell 2005). The "Spanish flu" was the most deadly influenza pandemic in history, killing an estimated 50 million people worldwide. The novel strain of that particular virus was never isolated in the laboratory. It quickly disappeared from the human population and was replaced by other, less virulent strains of the virus. Then, almost a century later,

a team of U.S. researchers successfully reconstructed the virus in the test tube, 
cuan_1146 can2008.cls February 22, $2012 \quad 14: 0$

rebuilding the pathogenic agent from its recovered genetic sequence. According to the researchers, the scientific reason for the resurrection of the virus was to examine the biological mechanisms that may have contributed to the virus's extraordinary morbidity and mortality. Such research, the scientists suggested, might eventually lead to effective forms of public health protection against future pandemics.

As Dr. Palese, the Chair of the Department of Microbiology at Mount Sinai recalled in a conversation with me, the research conducted with his colleagues, Dr. Jeffery Taubenberger of the Armed Forces Institute of Pathology in Rockville, Maryland, and Dr. Terrence Tumpey of the CDC, originally began in 1995. Small samples of infected human tissues soaked in formalin and sealed in paraffin at the Armed Forces Institute, in addition to a few specimens recovered by a certain Johann Hultin from a frozen corpse of an Inuit woman in Brevig Mission, Alaska, allowed Taubenberger to sequence bits and pieces of the virus's genetic information. By means of a sophisticated technology known as reverse genetics, adapted for influenza research by Dr. Palese in the late 1980s, and frequently used in his laboratory, a replication of the actual virus was reconstructed in the test tube. First, plasmids were constructed at Mount Sinai on the basis of the sequence information provided by Taubenberger. In cell cultures, the genetically engineered plasmids generated proteins, which then assembled into functional particles. Following stringent biosafety procedures, the genetic information was turned into viral matter in Dr. Tumpey's laboratory at the disease control centers in Atlanta. Dr. Tumpey finally injected the fully re-created virus into fertilized chicken eggs, the standard growth medium in influenza research. He then infected ferrets and mice with the agent. The results of the reconstruction were published in Science on October 7, 2005 (Tumpey et al. 2005). ${ }^{2}$

As Dr. Palese told me, on September 27, 2005, the editorial board of Science received an unexpected call from the Office of the Secretary of the U.S. Department of Health and Human Services (HHS). In this call, serious security concerns were signaled regarding the research article. A flurry of conference calls and electronic messages followed in which Assistant Secretary Stewart Simonson eventually declared that the secretary of the department insisted on additional review of the article by the recently established National Science Advisory Board for Biosecurity (NSABB) - a permanent federal body of 25 voting members who are considered experts in the fields of science, medicine, and security and whose prime function is to recommend policies. As the issue of Science was being printed, Simonson announced that he had ordered the advisory board to be polled. The advisory board "gave the paper an unusual last-minute review to make sure the merits of 
cuan_1146 can2008.cls February 22, $2012 \quad 14: 0$

its publication outweighed the risks of releasing potentially dangerous knowledge" (Kaiser 2005:28). The board voted unanimously in favor of publication, requiring the journal to add a special note explaining the general purpose of the research.

A series of newspaper articles about the resurrection of the virus had already appeared before the scientific experiments had been completed, establishing a space of "scandalous publicity," to use Lawrence Cohen's apt phrase; a space, in other words, in which a public is formed "in the enunciation of scandal" and in which there is growing political pressure to take a stance and either defend or denounce the matter at stake (Cohen 1999:147, 2011 :33). In an April 2005 Washington Post article, Wendy Orent suggests that "the feverish anxiety of public health officials to head off a new influenza pandemic may be generating the greatest influenza threat we face." As Orent reasoned, once the genetic information is in the public domain, "the entire 1918 flu could be built from scratch by anyone, anywhere, who has sufficient resources and skill." And she added, "it is quite conceivable that resurrected 1918 flu could someday be used as a bioterrorist [sic] agent." Charles Krauthammer, a syndicated Washington Post columnist, refers to the reconstruction of the 1918 virus as a "scientific achievement of staggering proportions" (2005:A19). Yet beyond the semblance of scientific brilliance, cautioned Krauthammer, "lies the sheer terror." He accused the researchers responsible for "the most momentous event of our lifetime" to have opened the "gates of hell" by publishing the entire sequence of the virus "for the whole world, good people and very bad, to see" (Krauthammer 2005:A19).

At the center of the public scandal produced in the news media around the resurrection of the microbial creature was the circulation of scientific information. The circulation of such information in the public domain was generally considered a significant condition of possibility, enabling its potential misappropriation by malicious actors. In the next section I explore the problematic of circulation as a constitutive concern of the apparatus of security.

\section{SECURITY AND THE PROBLEMATIC OF CIRCULATION}

Foucault's approach has the general advantage of avoiding the reduction of security to a set of mechanisms for the prevention of war. In Foucault's work, security comes into view primarily in relation to a historically distinctive problematic. As he argued in Security, Territory, Population, the constitutive concern of security turns on the optimal circulation of people, goods, and things (Foucault 2006; see as well Thacker 2009). In contrast to both the apparatus of sovereignty and the apparatus 
that must be modified in accordance with their intrinsic qualities and tendencies. For Foucault, a security apparatus does not seek to transform all the material givens it encounters in the world; it rather operates with a rationality of the maximization of positive elements and the minimization of negative elements. The problem, Foucault pointed out, is no longer that of "fixing and demarcating the territory, but of allowing circulations to take place, of controlling them, sifting the good and the bad, ensuring that things are always in movement, constantly moving around, continually going from one point to another, but in such a way that the inherent dangers of this circulation are cancelled out" (Foucault 2006:91). For the apparatus of security, the circulation of people, goods, and things thus constitutes the target of intermittent intervention, not total reformulation. It is only when certain forms of circulation begin to destabilize other forms that they must be controlled and curtailed. The crucial question, as Foucault puts it, is thus the following: "How should things circulate or not circulate?" (Foucault 2006:64).

Given its constitutive concern with the regulation and modulation of circulation, it is hardly surprising to find the problem of infectious disease taken up by the security apparatus. In a world that has increasingly learned to describe itself in the symbolic form of "globalization" (Tsing 2000) and in which the metaphor of "flow" has become "global common sense" (Zaloom 2006:3), concerns with the threat of the spread of diseases have appeared at the center of a reconfigured order of "post-Cold War terrors" (Comaroff 2007:198). Among the key issues for public health professionals who have begun to address the problem of emerging infectious diseases in a global context is how to facilitate the flow of people, goods, and things without abolishing the possibility of circulation in attempts to secure such flows. Thus, endemic to the apparatus of security is a fundamental tension between the necessity to promote and facilitate circulation, on the one hand, and the imperative to regulate and modulate circulation, on the other hand. My aim here, however, is not so much to analyze the contradictory principles at the heart of security in the context of late liberalism but to track how the apparatus of security is reinvented and reconstructed in relation to a reconfigured order of public health threats.

Today, the focus of the apparatus of security is not only on infectious diseases but also on efforts to promote scientific research for the control and prevention of infectious diseases. Scientific research itself, in other words, is now considered a potential threat. The successful reconstruction of the 1918 virus is one of many examples. ${ }^{3}$ At issue was always the potential release of a pathogenic agent, to be sure, but the crucial problem was often located elsewhere. What drew the most attention was not so much the potential circulation of dangerous biological 
matter but, rather, the exchange of sensitive scientific information. What has come into being as a result of this concern with the flow of information is "a map of misreading."

\section{THE MAP OF MISREADING}

In the aftermath of September 11, 2001, and the subsequent anthrax scare in the United States, biologists faced growing concerns that scientific information generated in the name of public health and its protection may be exploited by terrorists for malicious purposes (Check 2002; Petro and Relman 2003). Facing rising public fears and growing political efforts to promote a new category of information termed "sensitive but unclassified" (see Knezo 2004; Masco 2010; Shea 2003), a meeting of scientific publishers and editors was convened in January 2003 to discuss the potential security implications of biological research. Increasingly embroiled in politically charged struggles over the legitimacy and accountability of biological research, leading journals responded to the political pressure in late February. Both Science and Nature released editorial statements on scientific publication and security, recognizing that "the prospect of bioterrorism has raised legitimate concerns about the potential abuse of published information. ${ }^{\text {"4 }}$ In their statements, the editors vehemently rejected a formal role of the federal government, instead advising journals to take seriously their responsibility in determining what constitutes sensitive information by designing appropriate procedures for the identification of potential risks. In October of that year, the National Research Council of the National Academies published Biotechnology in an Age of Terrorism - also known as the Fink report - about technological advances that might be abused for nefarious purposes (NRC 2003). The report suggested a series of modifications to resolve the so-called dual-use dilemma, among them a systematic review of biological experiments and scientific publications for potential security implications (Atlas and Dando 2006).

At the center of this emerging apparatus of security is a particular concern, namely, the concern over the possible misappropriation of scientific information. In this context, the security apparatus has begun to address the problem of catachresis, and in so doing it has simultaneously promoted a distinctive linguistic model. Whatever the intended audience of a sign, insofar as it operates as a sign in the natural economy of language, it can always come under the influence of unforeseen readers. There is, in other words, forever the possibility of other contexts and other circumstances in which other meanings may prevail. Foregrounding the

fundamental capacity of the sign to break with the context of its original enunciation, 
this linguistic model, increasingly operating at the heart of security, seems to reject the logocentric premises of a theory of language, in which the consciousness of the speaking subject is made the prime source of meaning. Significantly, this model also recognizes the possibility of failure, that is to say, the inescapable risk of infelicity, uncertainty, and ambiguity to which every enunciatory act always remains liable. It is important to underline here that the determination of meaning nevertheless continues to be context bound in this model. As Jonathan Culler astutely observed, "meaning is context-bound, but context is boundless" (Culler 1981:24). What will remain impossible is to limit context, so as to determine the true meaning of a sign.

The recognition of the natural force intrinsic to the sign to break with context and escape the author's control has a long and complex history in modern understandings of language. It has also become an important concern in anthropological debates. ${ }^{5}$ Yet my aim here is not so much to rely on a theory of the sign for the analysis of the empirical material. Rather, I propose to trace a theory of the sign, which is already embedded in the empirical material itself. What I suggest, in other words, is to approach the matter of security "sideways." The methodological advantage of approaching security sideways is to avoid taking for granted "the difference between things and forms of explanation or abstraction" as Stefan Helmreich noted in his work on marine microbiology (Helmreich 2009:23). I thus treat theories (incl. theories of the sign) both as "tools for explaining worlds and as phenomena in the world to be examined" (Helmreich 2009:23; see as well Strathern 1988). Because of the particular theory of the sign embedded in the stuff of security, my object of analysis becomes the very effort to search semiotic materials for a certain type of meaning, which might be realized in the future.

In the context of infectious disease research, the sign increasingly comes into view as an object acquiring its meaning not from its present but from its future referent. What comes into existence as a result of this effort that builds on the intrinsic ability of the sign to break from its context and graft itself onto other structures of signification and acquire a new meaning is what we might call, with literary critic Harold Bloom firmly in mind, "a map of misreading" (Bloom 2003). Today, terrorists are primarily imagined as malicious agents who deliberately exploit the public traffic of the sign, misappropriating the informational products of scientific labor circulating in a global system of generalized exchange. The challenges of security are therefore to anticipate such misprision and to mitigate the vulnerability of the scientific speech act. At the heart of the emerging apparatus of security is the semiotic logic of iterability, the ability of 
cuan_1146 can2008.cls February 22, $2012 \quad 14: 0$

CULTURAL ANTHROPOLOGY 27:2

the sign to break from its context and acquire a new meaning. The sign, in this account, appears to be driven by a natural "force of rupture" and is never absolutely anchored in a given context; it can, on the contrary, always be spliced into other chains of signification and assume an unexpected set of meanings (Derrida 1988). ${ }^{6}$

Next, I continue my exploration of the biopolitical economy of security. My focus is on the emergence of a "nomadic geography" of the scientific sign in the context of infectious disease research. ${ }^{7}$ In doing so, I hope to expand recent work about the ways in which historically distinctive political practices are anchored in biological truth discourses. In my discussion, I specifically foreground a significant shift in the ontology of biological bodies that is at the heart of contemporary efforts to regulate the circulation of information in the biological sciences.

\section{SECURITY AND THE MICROBIAL BODY IN-FORMATION}

The characteristic features of our contemporary immunopolitics in an "age of security" have recently been examined in a set of sweeping articles published by a group of critical thinkers (Braun 2007; Cooper 2006; Dillon 2003). What Bruce Braun, Melinda Cooper, and Michael Dillon roughly share is a common diagnosis that lies at the core of their theoretical interventions. At stake is, most broadly stated, the politics of life in the philosophical tradition of Foucault. In his lectures, Foucault developed his productive notion of security, at least to some extent, in relation to the epidemiological thought and practice of the late 18 th and early 19 th centuries. ${ }^{8}$ The ascendancy of microbiology in the 20th century marks a significant break in the scientific understanding of infectious diseases and their presumable causes. The emergence of a reconfigured epistemological and ontological order in the 20th century, promoted by microbiology and its distinctive approach to living matter, suggests that a reconsideration of Foucault's original account of security is overdue. Political struggles in which infectious diseases figure as central objects of contestation have increasingly taken another shape because scientific understandings of epidemic events have changed in significant ways.

For Braun, Cooper, and Dillon, the molecular revolution has fundamentally changed our understanding of the biological itself. Not only has biological life been molecularized, as Nikolas Rose (2001) notably proposes, but also has become contingent, unpredictable, and emergent. "Molecularized life is ... contingent life," Dillon argues (Dillon and Lobo-Guerrero 2009:16; see also Dillon 2007; Dillon and Reid 2009). In the molecular age, "life" appears as relentlessly emerging and 
constant" (Cooper 2008:35). Far from generating a stable form of existence, biological bodies now appear as if they were "thrown into a chaotic and unpredictable molecular world filled with emergent yet unspecifiable risks" (Braun 2007:7). For Braun, Cooper, and Dillon, the "precarious body" constitutes a new challenge for the apparatus of security, posing the crucial question about how this body should or should not circulate. The growing concern with security represents a political response to the indeterminate, contingent, and aleatory character distinctive of the "molecular vision" of the biological body (Kay 1996).

The work of Braun, Cooper, and Dillon opens up a promising line of inquiry and scrutiny, enabling scholars to explore contemporary reconfigurations of the apparatus of security beyond Foucault's original account. Such reconfigurations are occurring today, not least because biological bodies have been transformed by an "art of continuous modulation, in which form is plunged back into process, becoming continuously remorphable" (Cooper 2008:123). As Donna Haraway underscored in her seminal essay on the biopolitics of postmodern bodies (Haraway 1991), the destabilization of the hierarchical, localized, fixed organic body as a principal anchor of biopolitical practice has resulted in a different kind of biopolitics, a biopolitics of postmodern bodies. It is precisely such a postmodern body that is at the heart of the emerging economy of security today, a body that is just as much semiotic as it is corporeal. As a result of the ascendancy of molecular biology and its "biotechnical touch," to use Hannah Landecker's felicitous phrase (2005), biological bodies have increasingly begun to circulate in informational forms, rather than corporeal ones. The fact, however, that the biological body is circulated and exchanged in informational forms does not imply that this body is somehow not material; the body in-formation has, on the contrary, its own distinctive materiality (Hayles 1999; Stevens 2011; Thacker 2006).

We can now see that the changing ontological form of the biological bodywhich increasingly finds itself entangled in a permanent process of formation and reformation and is problematized in terms of a generalized economy of exchange and circulation - has affected the biopolitical apparatus of security in the United States. In the remainder of this article, I examine the ontological form of the biological body and I show how its changing form has both stabilized and destabilized the security apparatus. My aim is to bring into better relief the tensions, contradictions, and contestations that have begun to manifest themselves in recent years and that are not explored in the accounts of Braun, Cooper, and Dillon. What I have referred to here as "iterability" permits a critical analysis of the fissures and fractures in today's biopolitical economy of security. 


\section{ITERABILITY AND THE MICROBIOLOGICAL ONTOLOGY OF THE} PATHOLOGICAL

Aware of the fundamental ability of information to be detached from its original context, the security apparatus has become concerned with the public circulation and potential misappropriation of sensitive information. Nevertheless, in the conversations that I conducted and in the debates that I witnessed during my fieldwork, such information was simultaneously recontextualized. This should come as no surprise at all, to be sure, for "one cannot do anything, least of all speak, without determining (in a manner that is not only theoretical, but practical and performative) a context," as Jacques Derrida observed (Derrida 1988:136). The moment of detachment, in other words, is always also a moment of reattachment, and the logic of iterability therefore constitutes the condition of possibility of both detachment and reattachment.

In the course of my research, I increasingly realized that biologists of information frequently responded to security demands with a biology of context. ${ }^{9}$ What eventually came into view was not so much a situated science but a situating science - not a contextualized biology but a contextualizing biology, a biology of context. When I asked Dr. Palese about the publication of the controversial article, he stated:

"We felt very strongly that the paper should be published. There was no reason that it shouldn't. At the time we already knew for example that the 1918 virus can be inhibited by anti-influenza virus drugs, which, I think, is very important."

In his conversations with me, Dr. Palese always insisted that the public perception of the 1918 virus as a "microbial monster" was inadequate. His view of the virus was based on a series of experiments conducted in advance of the article's publication. These experiments were designed to assess whether vaccines for regular seasonal flu would provide protection against recombinant viruses, which contained the immunologically relevant genes derived from the 1918 virus. They were conducted to contextualize the virus in contemporary circumstances, and they confirmed Dr. Palese's assumption that current vaccines would protect in part because the 1918 virus belongs to the same subtype of the influenza virus (H1N1) that is currently circulating in the human population. In addition to these experiments, the scientists tested the efficacy of four antiviral drugs, which also proved effective. ${ }^{10}$ 
In his characteristically blunt and plain-speaking manner, Dr. Palese suggested that there was no justification in his view to classify the 1918 virus as a "select agent":

Very recently we have published a paper where we showed that you actually can protect against the 1918 virus with the current vaccine for the H1N1 influenza virus. With an influenza virus that is fairly similar to the 1918 virus, we already have a population which is almost completely protected against the 1918 virus. The fact that the regular vaccine formulation protects against the 1918 virus brings this virus into the realm of regular influenza viruses and does not justify people making it a select agent and preventing researchers from working on it. It's completely unjustified. Drugs work, vaccines work, I mean, what else do we have to have? ${ }^{11}$

Nevertheless, security reports released by state agencies frequently invoked the resurrection of the 1918 virus as an illustrative example of the new dangers produced by contemporary biological research. The fact that both regular antiviral drugs and regular flu vaccines had been shown to work against the 1918 virus was never taken into account systematically. Dr. Palese also emphasized that the entire human population was now carrying a partial immunity to the 1918 virus, especially after the most recent pandemic, which was caused by a similar strain of the virus. "So by learning all this, by knowing all this, I think this is very important information," he underscored. Microbiologist Dr. Richard Ebright, who questioned Palese's research in 2005, concurred in an interview with me, explaining that his comments about the resurrection of the 1918 virus "only apply to the situation as of October 2005, when the reconstruction of the 1918 virus was published.” These comments, he continued, "may not fully apply to the situation after October 2009, due to the immunological impacts of the H1N1 pandemic." Despite these qualifications, the virus was eventually classified as a "select agent" by the U.S. government. The availability and effectiveness of immunizations and antiviral therapies to prevent infection and treat illness were not taken into consideration. What appeared to be more important, by contrast, was the public debate about the potential "threat," which created its own performative effect. The very fact of a growing debate about a potential threat seemed to make the security response inevitable.

In the course of my work with Dr. Palese, I increasingly understood that he should not just be seen as a biologist of information but also, and perhaps primarily, as a biologist of context. In our conversations about pandemic influenza, he was always careful to consider the pathogenic agent in its biological milieu, 
cuan_1146 can2008.cls February 22, $2012 \quad 14: 0$

emphasizing its relationships with other entities. In so doing, he systematically avoided the reification of the virus as an organic totality set apart from other organic totalities. For Dr. Palese, its resemblance to other strains of the virus, its susceptibility to antiviral drugs, and its responsiveness to current vaccines were critical. It was impossible to talk about the 1918 virus without simultaneously talking about its hosts. For the virus it thus seemed difficult to have an identity prior to being brought into relation with other bodies, human and nonhuman. What I learned from Dr. Palese is to understand the pathological as an encounter and, therefore, as a relative value. Disease, I concluded, must be conceived of as an ever-shifting, ever-changing relationship.

Iterability is the general condition that has made the decontextualization of microbial bodies in-formation possible. But it has concomitantly made the recontextualization of these bodies necessary, biologically as well as politicallyand that is to say biopolitically. The articulation, contestation, and negotiation of the security demands that have been proposed over the past few years take place now in terms of a biology of context or, as Landecker might phrase it, in terms of a "relational biology" (2011:169): "Rather than pursuing the qualities and quantities intrinsic to living things - their genetic sequences, their functional structures - these relational approaches are more likely to focus on the biology of the in between" (Landecker 2011:168). For Dr. Palese, it was this space in between that was most productive, scientifically as well as politically.

In the final section of this article, I explore Landecker's suggestion in more detail and examine how experts concerned with security have determined "sensitive information" in the context of contemporary infectious disease research. How exactly is "sensitive" information distinguished from other, presumably less sensitive information? How is the infinitely expandable category of "sensitive information" actually defined? What principles for the containment of the category are mobilized in this emerging economy of security?

\section{TAXONOMIC TROUBLE}

What may be the most informative research... must surely be the most dangerous as well.

—Jamie Shreeve, New York Times

In early 2006, the federal government charged the NSABB to examine the potential risks posed by the synthetic construction of biological agents in research labora-

tories. ${ }^{12}$ Specifically, the board was asked to assess whether pathogenic agents 
cuan_1146 can2008.cls February 22, $2012 \quad 14: 0$

generated by means of reverse genetics (such as the 1918 virus) escape the purview of the existing regulatory system established under the Public Health Security and Bioterrorism Preparedness and Response Act of 2002. As the NSABB noted in a report, technologies such as reverse genetics and the open availability of genetic information on public data banks "have raised concerns in the scientific community and general public regarding the possible use of this technology and information to generate biological agents that could threaten public health" (NSABB 2006:2). The board further reported, "approaches based on de novo synthesis avoid any need for access to the naturally occurring agents or naturally occurring nucleic acids from these agents" (NSABB 2006:2). Significantly, the kind of genetic information allowing researchers to synthesize these pathogenic agents in the laboratory by means of reverse genetics is available online. Given the new technological capabilities, experts concerned with security have argued that it is necessary to establish a new regime of governance reaching beyond the current regulation of dangerous matter (Bügl et al. 2007). What must be controlled and curtailed is not only the circulation of dangerous biological matter but also the exchange of sensitive scientific information because of the general availability of the technology.

The simplest and cheapest way for a scientist to design and construct (or redesign and reconstruct) a microbial body in-formation is to order a gene or a full genome online from a commercial firm. As of 2012, approximately 45 private companies provide researchers with this essential service. Typically, researchers place orders for several small pieces of DNA that they then assemble on their own. In the laboratory, experimental work with microbial bodies in-formation often drew the scientists with whom I worked into lively discussions about the quantity of plasmids, the quality of reagents, the purity of cells, the temperature of agar, and the fate of bad hands. The technical procedures required to sustain this peculiar type of biological materiality were inevitably fraught with considerable contingency and created a certain anxiety, especially among graduate students in the laboratory. The techniques to culture bodies in-formation remain remarkably precarious and seem to require what Evelyn Fox Keller once identified as a "feeling for the organism” and what I might call a sensibility for its milieu (Fox Keller 2001). Although a routine procedure in research laboratories, both private and public, the construction of a virus in the test tube is neither simple nor straightforward. It is, on the contrary, a complex technical craft, fraught with failures. It is based on a highly skilled labor and requires patience, experience, and luck. Simply following the standard protocol as others have developed is no guarantee for sure success. 
cuan_1146 can2008.cls February 22, $2012 \quad 14: 0$

The effort to create the right milieu in the laboratory turns out to be essential for the successful animation and circulation of microbial bodies in-formation.

In their efforts to determine what kind of information might present the greatest concern, security experts initially suggested that scientific information concerning the most dangerous agents concomitantly constitutes the most sensitive information. Here, then, a certain classification of dangerous biological matter served as a model for the classification of sensitive scientific information. Charged to identify sensitive scientific information, experts thus invoked the presumably stable ground of dangerous biological matter and its current taxonomical classification. However, as the NSABB report concurrently noted, genomic research has increasingly begun to challenge such classifications. As the report argued,

Studies of human pathogens using genomics-based approaches have revealed an enormous level of strain diversity that has challenged our notion of microbial species as discrete entities with well-defined properties. This diversity in large part reflects the fact that microbial genomes are dynamic entities shaped by multiple forces, including acquisition of new functions via lateral gene transfer. One implication of these observations is that in some instances the assignment of a genus/species name to an organism may be difficult, and of limited utility, in predicting the phenotypic properties of a particular isolate, in particular with regard to virulence, infectivity and pathogenicity. Therefore, the genus/species based approach that is currently used in Select Agent classification is imperfect since it does not take into account the great degree of genetic variability that can exist within species as they are currently defined. [NSABB 2006:13]

The fact that scientists are constructing and reconstructing microbes in the laboratory on a regular basis using combinations of genetic materials derived from different species has gradually begun to reveal the limits of a biopolitical economy of security, which is based on tidy taxonomic definitions, permanent organic substances, and stable genetic essences. New microbial creatures, which blur the boundaries of species - and thus challenge the very concept of the "species" — are potentially equipped with equivalent properties as select agents, but they may not necessarily fit into the taxonomic tables of the classical Darwinian sort. Such organisms thus increasingly seem to become illegible in a regime in which legibility primarily depends on affixing a genus or species name on a microorganism. Here, then, the experimental practice of reverse genetics - or the ability of researchers to take 
in-formation by technical means - appears to have destabilized a regime, which derives its standards of evaluation from a taxonomic system of classification. Taking into account that microbial genomes are now considered dynamic, ever-shifting entities, shaped by multiple forces, both natural and technical, tidy taxonomic tables increasingly prove less than adequate to reliably predict pathogenic effects. Reverse genetics is a powerful cut-and-paste technology taking advantage of the logic of iterability. Relentlessly replicating, recombining, and rearranging genetic materials in the test tube, and thereby constructing and reconstructing microorganisms in the artificial environment of the laboratory, researchers have successfully tied repetition to alterity and turned iterability into a generative principle of experimental practice. Genetic sequences are decontextualized and recontextualized on a regular basis, and new microbial bodies in-formation with "uncertain ontologies" are produced along the way (Lowe 2010). These new creatures call for a relational biology and increasingly disrupt conventional efforts to provide biological bodies with a proper name and a proper place in an evolutionary genealogy of microbial descent.

It would be a mistake, however, to suggest that iterability can be observed only inside the laboratory. The logic of iterability is at the heart of both a technical procedure and a natural mechanism. As scientific studies have shown, microorganisms receive genetic materials not only from their ancestors but also from other organisms without necessarily being their offspring (Gogarten et al. 2009). Genes, in other words, are also transferred horizontally between organisms that are only distantly related. Such horizontal gene transfer has been explored by Helmreich in a 2003 article, where he argued that the lateral exchange of genetic material among microorganisms observed in the extreme ecologies around hydrothermal vents may contribute to the dissolution of the traditional relation between genealogy and taxonomy. In the case of microorganisms, the discovery of horizontal gene transfer is now encouraging scientists "to give up the notion of species for recombining microbes," as suggested in a recent account on the epistemological impacts of horizontal gene transfer (Bapteste and Boucher 2009:71). Helmreich underscored that the "taxonomic untidiness such microbes have introduced through their lateral gene transfer reaches beyond issues in phylogeny and molecular systematics into arenas adjacent to kinship concerns and biopolitics" (Helmreich 2003:341; see also Helmreich 2009). "When genes become information and are made legible through gene sequencing and bioinformatics," Helmreich reasoned, "the biopolitics that result may well be new" (Helmreich 2003:341).

If the microbiological ontology of the pathological offered modes of classification and standards of evaluation allowing experts to establish normative principles 
for the biopolitical economy of security and to determine the kind of circulations that must be controlled and curtailed, then the logic of iterability has profoundly undermined this ontology. The fact that some pathogenic agents are inherently less "dangerous" than others does not necessarily mean that the genetic sequences of these agents are equally "harmless." Because of the high sequence similarity of some select agents with other organisms, the genetic sequence of a "harmless" organism may ultimately prove just as "dangerous" as the genetic sequence of an organism officially classified as a select agent. Seeking to define "sequences of concern," a series of guidelines were released in October 2010, which recognized that genetic sequences not unique to select agents exist that may also pose a security concern (HHS 2010).

Today, the biopolitical economy of security is not only preoccupied with a distinctive practice (the public exchange of information) and with a distinctive problem (information's essential iterability) but also confronted with a new challenge caused by the disruption of a form of regulation and modulation, which is based on the taxonomic identification of microbial organisms. Consequently, we are witnessing new excesses of biopower that are the result not only of the technological possibility of building viruses that cannot be controlled but also the technological possibility of building viruses with information that cannot be contained.

\section{EPILOGUE}

At the heart of the current attempt to regulate biological research is the circulation of information. As Evelyn Fox Keller, Lily Kay, and others have shown, information is a rather problematic and confusing concept, especially in the biological sciences (Fox Keller 2000; Kay 2000; see also Gere and Parry 2006). Yet although information appears to be confusing as a concept, it has nevertheless been incredibly productive, perhaps precisely because it is so confusing in the first place (Rheinberger 2000). Confusing (and confusingly productive) as it may be, information has operated as a generative "boundary concept," establishing relations between separate and separated domains (Star and Griesemer 1989). Today, the boundary concept of information has become a driving force reconfiguring relations among science, security, and the state. As a result, biologists of information such as Dr. Palese, Dr. Maines, and Dr. Tumpey are now unexpectedly drawn into expanding debates about the security implications of their work. A biology that has increasingly become informational has attached them in unexpected ways to the 
information have always insisted on the stringent safety precautions that must be observed in the laboratory, but they have concomitantly stressed the importance of publishing the results of experimental research without externally imposed limitations or restrictions. It is their belief that such a strategy of safety and precaution is both improving science and protecting the public's health.

Underwriting this belief is the liberal imaginary of an unrestricted exchange and free sharing of information. This imaginary is, of course, itself a constitutive element of the founding myth of modern science. It would be a mistake, therefore, to consider it an adequate description of the actual practice; it should rather be seen, historian of science Robert Kohler suggested, as the articulation of a moral code (Kohler 1994:134). With Kohler's Lords of the Fly in mind, it is fair to say that this moral code continues to shape the way scientists perceive themselves today. ${ }^{13}$ This perception also accounts for the fact that scientists have frequently declared that security concerns and intellectual property rights are increasingly straining the moral economy of scientific exchange in which they are supposed to participate. At stake in these debates are thus questions about the moral foundations of the scientific community. There is no doubt that the notion of information continues to be essential for the relational understanding of the biological that biologists of information are currently promoting. But the notion also constitutes a central element of their moral identity as scientists engaged in social relationships mediated by the public exchange of scientific information. As a boundary concept, the notion of information thus structures both a scientific understanding of biology and its moral foundation as a science based on social relationships mediated by a form of exchange. Today's biologists of information are engaged in the difficult effort of constructing a biology of context, reflecting the crucial question of what it means to be a scientist.

Scientific discourse is public discourse, and public discourse has committed itself, in principle, to the potential participation of strangers. Abandoning the safety and security of its given audience and pursuing an ethics of estrangement, public discourse systematically "puts at risk the concrete world that constitutes its condition of possibility" (Warner 2005:113). Today's challenge, therefore, is to cultivate a mode of practice beyond security as a liberal technology of power. Such a mode of practice would allow biologists of information to sustain the "fruitful perversity" of the scientific speech act without producing a world in which knowledge becomes suspect (Masco 2010). It may very well be that the meaning of both the biologists and the biology of information must be remade along the way. 


\begin{abstract}
In this article, I investigate the biopolitical economy of security as it is operating today in the United States in the context of infectious disease research. Drawing on my work with influenza researchers, I specifically show how experts have been concerned not only with the circulation of biological matter but also with the exchange of scientific information. I argue that it is a specific logic - the logic of iterability - that is at the heart of the growing concern with "sensitive information" published in scientific journals. How has the concern with sensitive information affected infectious disease research in the United States in the past few years? How has the logic of iterability reconfigured microbiological notions of the normal and the pathological? And what might an anthropological analysis of the biopolitical economy of security be able to tell us about the ways in which "life" is made a new political concern today?

\section{NOTES}

Acknowledgments. My gratitude to Peter Palese, Taronna Maines, and Terrence Tumpey for making my research possible. I would also like to thank Roger Begrich, Alberto Cambrosio, Lawrence Cohen, Stephen Collier, Cori Hayden, Angie Heo, Julia Hornberger, Karine Landgren Hugentobler, Karen Jent, Evangelos Karagiannis, Frédéric Keck, Chris Kelty, Nikolas Kosmatopoulos, Andy Lakoff, Hannah Landecker, Nicolas Langlitz, Andrea Mühlebach, Elizabeth Povinelli, Paul Rabinow, Kaushik Sunder Rajan, Shalini Randeria, Peter Redfield, Tobias Rees, Anthony Stavrianakis, Miriam Ticktin, Fouzieyha Towghi, and Alexei Yurchak for helpful suggestions and generous support of my work. Thanks are owed as well to the anonymous reviewers and the editors of Cultural Anthropology, Anne Allison and Charles Piot, for their invaluable comments. Funding for this research was provided by the Swiss National Science Foundation.
\end{abstract}

1. For additional examples, see Bingham and colleagues (2008); Collier and colleagues (2004); King (2002); and Lentzos and Rose (2009).

2. Before the experiments were conducted, CDC's Institutional Biosafety Committee reviewed the proposed research extensively. All experimental procedures were carried out in a biosafety level 3-enhanced facility, which includes controlled access, systematic decontamination as well as primary safety barriers (safety cabinets, isolation chambers, gloves, and gowns) and secondary safety barriers (special facility construction with restricted access and high-efficiency particulate air filtration) to protect the scientists and the public from accidental exposure. The enhanced procedures used for the reconstruction of the 1918 virus include additional respiratory protection, clothing changes, and personal showers prior to exiting the laboratory. All laboratory workers were also required to take antiviral prophylactics while conducting the experiments. Here, I will not provide further detailed analysis of these precautions, focusing instead on efforts to regulate and modulate the exchange of sensitive scientific information.

3. For others, see the list provided in Fink (2003).

4. See Atlas and colleagues (2003).

5. To mention just one among many other accounts, see Urban 1996.

6. See as well Das (2004). My thanks to Lawrence Cohen for bringing Veena Das's important essay to my attention and for engaging my work on the matter of security more generally.

7. The term nomadic geography is Helmreich's (2003:208).

8. Of equal importance for Foucault's understanding of security was of course the physiocratic thought of the 18 th century.

9. I am indebted to Hannah Landecker, who suggested these terms to me.

10. This argument presupposes that such vaccines and antiviral drugs are readily available, which might not necessarily be the case. 
cuan_1146 can2008.cls February 22, $2012 \quad 14: 0$

11. Select agents are pathogenic organisms or toxins that have been declared by U.S. government agencies to have a potential to pose a significant threat to public health.

12. The challenges presented by techniques of recombinant DNA were addressed in 1975 at the historic Asilomar conference in Pacific Grove, California, where scientists from around the world gathered to discuss the potential hazards of genetic engineering. These discussions established the foundations of most contemporary safety practices in the biological sciences. The focus at Asilomar was mainly on environmental safety issues and therefore differs considerably from the problematization of the biological sciences in terms of security. On the Asilomar conference, see Hindmarsh and Gottweis (2005) and Krimsky (2005).

13. Thanks to Peter Redfield for reminding me here of Kohler's important work.

\section{REFERENCES CITED}

Atlas, R. M., P. Campbell, N. R. Cozarelli, G. Curfman, L. Enquist, G. Fink, A. Flanagin, J. Fletcher, E. George, G. Hammes, D. Heyman, T. Inglesby, S. Kaplan, D. Kennedy, J. R. LevinsonKrug, E. Marcus, H. Metzger, S. S. Morse, A. O’Brien, A. Onderdonk, G. Poste, B. Renault, R. Rich, A. Rosengard, S. Salzburg, M. Scanlan, T. Shenk, H. Tabor, H. Varmus, E. Wimmer, and K. Yamamoto

2003 Statement on Scientific Publication and Security. Science 299:1149.

Atlas, Ronald M., and Malcom Dando

2006 The Dual-Use Dilemma for the Life Sciences. Perspectives, Conundrums, and Global Solutions. Biosecurity and Bioterrorism 4(3):276-286.

Atlas, Ronald M., and Judith Reppy

2005 Globalizing Biosecurity. Biosecurity and Bioterrorism: Biodefense Strategy, Practice, and Science 3(1):51-60.

Bapteste, Eric, and Yan Boucher

2009 Epistemological Impacts of Horizontal Gene Transfer on Classification in Microbiology. In Horizontal Gene Transfer. Genomes in Flux. J. P. Gogarten, J. P. Gogarten, and L. C. Olendzenski, eds. Pp. 55-72. New York: Humana.

Bingham, Nick, Gareth Enticott, and Steve Hinchcliffe

2008 Biosecurity. Spaces, Practices, and Boundaries. Environment and Planning A 40(7): $1528-1533$.

Bloom, Harold

2003 A Map of Misreading. Oxford: Oxford University Press.

Braun, Bruce

2007 Biopolitics and the Molecularization of Life. Cultural Geographies 14:628.

Bügl, Hans, John P. Danner, Robert J. Molinari, John T. Mulligan, Han-Oh Park, Bas Reichert, David A. Roth, Ralf Wagner, Bruce Budowle, Robert M. Scripp, Jenifer A. L. Smith, Scott J. Steele, George Church, and Drew Endy

2007 DNA Synthesis and Biological Security. Nature Biotechnology 25(6):627629.

Check, Erika

2002 Biologists Apprehensive over US Moves to Censor Information Flow.

Chong, Jia-Rui Nature 415(6874):821.

2006 Bird Flu Findings Cautiously Optimistic. Chicago Tribune. http://articles. chicagotribune.com/2006-08-01/news/0608010441_1_pandemic-strain-birdflu-avian-influenza, accessed January 21, 2012.

Cohen, Lawrence

1999 Where it Hurts. Indian Material for an Ethics of Organ Transplantation. Daedalus 128(4):135-165.

2011 Migrant Supplementarity. Remaking Biological Relatedness in Chinese Military and Indian Five-Star Hospitals. Body and Society 17(2-3):31-54. 
cuan_1146 can2008.cls February 22, $2012 \quad 14: 0$

Collier, Stephen J., Andrew Lakoff, and Paul Rabinow

2004 Biosecurity. Towards an Anthropology of the Contemporary. Anthropol-

Comaroff, Jean ogy Today 20(5):3-7.

2007 Beyond Bare Life. AIDS, (Bio)Politics, and the Neoliberal Order. Public Culture 19(1):197-219.

Cooper, Melinda

2006 Pre-Empting Emergence. The Biological Turn in the War on Terror. Theory, Culture and Society 23(4):113-135.

2008 Life as Surplus. Biotechnology and Capitalism in the Neoliberal Era. Seattle: University of Washington Press.

Culler, Jonathan

1981 Convention and Meaning. Derrida and Austin. New Literary History 13(1):15-30.

Das, Veena

2004 The Signature of the State. The Paradox of Illegibility. In Anthropology in the Margins of the State. V. Das and D. Poole, eds. Pp. 225-252. Santa Fe, NM: School of American Research Press.

Daston, Lorraine

1995 The Moral Economy of Science. Osiris 10:2-24.

Derrida, Jacques

1988 Signature Event Context. In Limited Inc. Pp. 1-23. Evanston, IL: North-

Dillon, Michael western University Press.

2003 Virtual Security. A Life Science of (Dis)Order. Millennium 32(3):531558.

2007 Governing through Contingency. Security of Biopolitical Governance. Political Geography 26:41-47.

Dillon, Michael, and Luis Lobo-Guerrero

2009 The Biopolitical Imaginary of Species-Being. Theory, Culture and Society 26(1):1-23.

Dillon, Michael, and Julian Reid

2009 The Liberal Way of War: Killing to Make Life Live. London: Routledge.

Epstein, Gerald L.

2002 Bioresponsibility. Engaging the Scientific Community in Reducing the Biological Weapons Threat. BioScience 52(5):398-399.

Fink, Gerald R.

2003 Biotechnology Research in an Age of Terrorism. Washington, DC: National Academies Press.

Foucault, Michel

2006 Security, Territory, Population. Lectures at the Collège de France, 1977-78. G.

Burchell, trans. London: Palgrave.

Fox Keller, Evelyn

2000 The Century of the Gene. Cambridge, MA: Harvard University Press.

2001 A Feeling for the Organism: The Life and Work of Barbara McClintock. New York: W. H. Freeman.

Galison, Peter

2004 Removing Knowledge. Critical Inquiry 31:229-243.

Gere, Cathy, and Bronwyn Parry

2006 The Flesh Made Word: Banking the Body in the Age of Information. BioSocieties 1(1):41-54.

Gogarten, Maria Boekels, Johann Peter Gogarten, and Lorraine C. Olendzenski, eds.

2009 Horizontal Gene Transfer: Genomes in Flux. New York: Humana. 
Grady, Denise

2006 Making a Ferret Sneeze for Hints to the Transmission of Bird Flu. New York Times.

Gusterson, Hugh

1996 Nuclear Rites: A Weapons Laboratory at the End of the Cold War. Berkeley: University of California Press.

Haraway, Donna

1991 Simians, Cyborgs, and Women. The Reinvention of Nature. New York: Routledge.

Hayles, N. Katherine

1999 How We Became Posthuman: Virtual Bodies in Cybernetics, Literature, and Informatics. Chicago: University of Chicago Press.

Helmreich, Stefan

2003 Trees and Seas of Information: Alien Kinship and the Biopolitics of Gene Transfer in Marine Biology and Biotechnology. American Ethnologist 30(3):340 358.

2009 Alien Ocean: Anthropological Voyages in Microbial Seas. Berkeley: University of California Press.

HHS

2010 Screening Framework Guidance for Providers of Synthetic Double-Stranded DNA. Washington, DC: HHS.

Hindmarsh, Richard, and Herbert Gottweis

2005 Recombinant Regulation: The Asilomar Legacy 30 Years On. Science as Culture 14(4):299-307.

Kaiser, Jocelyn

2005 Resurrected Influenza Virus Yields Secrets of Deadly 1918 Pandemic. Science 310:28-29.

Kay, Lily

1996 The Molecular Vision of Life: Caltech, the Rockefeller Foundation, and the Rise of the New Biology. Oxford: Oxford University Press.

2000 Who Wrote the Book of Life? A History of the Genetic Code. Stanford: Stanford University Press.

King, Nicholas B.

2002 Security, Disease, Commerce: Ideologies of Postcolonial Global Health. Social Studies of Science 32(5-6):763-789.

Knezo, Genevieve J.

2004 "Sensitive but Unclassified" and Other Federal Security Controls on Scientific and Technical Information. Washington, DC: Congressional Research Service.

Koch, Erin

2008 Disease as Security Threat. Critical Reflections on the Global TB Emergency. In Biosecurity Interventions. Global Health and Security in Question. A. Lakoff and S. Collier, eds. Pp. 121-146. New York: Columbia University Press.

Kohler, Robert E.

1994 Lords of the Fly: Drosophila Genetics and the Experimental Life. Chicago: University of Chicago Press.

Krauthammer, Charles

2005 A Flu Hope, or Horror? Washington Post, October 14: A19.

Krimsky, Sheldon

2005 From Asilomar to Industrial Biotechnology: Risks, Reductionism and Lakoff, Andrew Regulation. Science as Culture 14(4):309-323.

2008 The Generic Biothreat, or, How We Became Unprepared. Cultural Anthropology 23(3):399-428. 
cuan_1146 can2008.cls February 22, $2012 \quad 14: 0$

Lakoff, Andrew, and Stephen Collier

2008 Biosecurity Interventions: Global Health and Security in Question. New York: Columbia University Press.

Landecker, Hannah

2005 Living Differently in Time: Plasticity, Temporality and Cellular Biotechnologies. Culture Machine 7. http://www.culturemachine.net/index.php/ cm/article/viewArticle/26/33, accessed January 21, 2012.

2011 Food as Exposure: Nutritional Epigenetics and the New Metabolism. BioSocieties 6(2):167-194.

Lentzos, Filippa, and Nikolas Rose

2009 Governing Insecurity: Contingency Planning, Protection, Resilience. Economy and Society 38(2):230-254

Lowe, Celia

2010 Viral Clouds: Becoming H5N1 in Indonesia. Cultural Anthropology 25(4):625649.

Maines, Taronna R., Li-Mei Chen, Yumiko Matsuoka, Hualan Chen, Thomas Rowe, Juan Ortin, Ana Falcón, Nguyen Tran Hien, Le Quynh Mai, Endang R. Sedyaningsih, Syahrial Harun, Terrence M. Tumpey, Ruben O. Donis, Nancy J. Cox, Kanta Subbarao, and Jacqueline M. Katz

2006 Lack of Transmission of H5N1 Avian-Human Reassortant Influenza Viruses in a Ferret Model. PNAS 103(32):12121-12126.

Masco, Joseph

2006 The Nuclear Borderlands: The Manhattan Project in Post-Cold War New Mexico. Princeton: Princeton University Press.

2010 "Sensitive but Unclassified": Secrecy and the Counterterrorist State. Public Culture 22(3):433-463.

NRC

2003 Biotechnology Research in an Age of Terrorism. Washington, DC: National Academies Press.

NSABB

2006 Addressing Biosecurity Concerns Related to the Synthesis of Select Agents. Washington, DC: NSABB.

Orent, Wendy

2005 Playing with Viruses: Replicating This Flu Strain Could Get Us Burned. Washington Post, April 17: B1.

Petro, James B., and David A. Relman

2003 Understanding Threats to Scientific Openness. Science 302(5652): 1898.

Rheinberger, Hans-Jörg

2000 Gene Concepts: Fragments from the Perspective of Molecular Biology. In The Concept of the Gene in Development and Evolution: Historical and Epistemological Studies. P. J. Beurton, R. Falk, and H.-J. Rheinberger, eds. Pp. 219-239. Cambridge: Cambridge University Press.

Rose, Nikolas

2001 The Politics of Life Itself. Theory, Culture and Society 18(6):1-30.

Russell, Sabin

2005 Deadliest Flu Bug Given New Life in U.S. Laboratory. San Francisco Chronicle, October 6: A1.

Shea, Dana A.

2003 Balancing Scientific Publication and National Security Concerns. Washington, DC: Congressional Research Service.

Star, Susan Leigh, and James R. Griesemer

1989 Institutional Ecology, "Translations" and Boundary Objects: Amateurs and Professionals in Berkeley's Museum of Vertebrate Zoology, 1907-39. Social Studies of Science 19:387-420. 
Stevens, Hallam

2011 On the Means of Bio-Production: Bioinformatics and How to Make Knowledge in a High-Throughput Genomics Laboratory. BioSocieties 6(2):217-242.

Strathern, Marilyn

1988 The Gender of the Gift: Problems with Women and Problems with Society in Melanesia. Berkeley: University of California Press.

Sunder Rajan, Kaushik

2006 Biocapital: The Constitution of Postgenomic Life. Durham, NC: Duke University Press.

Thacker, Eugene

2006 The Global Genome: Biotechnology, Politics, and Culture. Cambridge, MA: MIT Press.

2009 The Shadows of Atheology: Epidemics, Power and Life After Foucault. Theory, Culture and Society 26(6):134-152.

Tsing, Anna

2000 The Global Situation. Cultural Anthropology 15(3):327-360.

Tumpey, Terrence M., Christopher F. Basler, Patricia V. Aguilar, Hui Zeng, Alicia Solórzano, David E. Swayne, Nancy J. Cox, Jacqueline M. Katz, Jeffery K. Taubenberger, Peter Palese, and Adolfo García-Sastre

2005 Characterization of the Reconstructed 1918 Spanish Influenza Pandemic Virus. Science 310:77-80.

Urban, Greg

1996 Entextualization, Replication, and Power. In Natural Histories of Discourse. M. Silverstein and G. Urban, eds. Pp. 21-44. Chicago: University of Chicago Press.

Vogel, Kathleen

2008 Biodefense: Considering the Sociotechnical Dimension. In Biosecurity Interventions: Global Health and Security in Question. A. Lakoff and S. Collier, eds. Pp. 227-255. New York: Columbia University Press.

Warner, Michael

2005 Publics and Counterpublics. New York: Zone.

Zaloom, Caitlin

2006 Out of the Pits: Traders and Technology from Chicago to London. Chicago: University of Chicago Press.

Editors' Notes: Cultural Anthropology has published a number of articles on security, including Celia Lowe's "Viral Clouds: Becoming H5N1 in Indonesia" (2010), Andrew Lakoff's "The Generic Biothreat, or, How We Became Unprepared” (2008), and Joseph Masco's ““'Survival Is Your Business”: Engineering Ruins and Affect in Nuclear America” (2008).

Cultural Anthropology has also published articles on biopolitical economy. See for example, Jean M. Langford's “Gifts Intercepted: Biopolitics and Spirit Debt” (2009), Anand Pandian's "Pastoral Power in the Postcolony: On the Biopolitics of the Criminal Animal in South India” (2008), and Peter Redfield's “Doctors, Borders, and Life in Crisis" (2005). 